\title{
What is it to be an Artist Teacher in England Today?
}

\author{
Alan Thornton ${ }^{1, *}$ \\ ${ }^{1}$ Anglia Ruskin University, Department of Education, Chelmsford, Essex, England \\ *Correspondence: Anglia Ruskin University, Department of Education, Chelmsford, Essex, England, CM11SQ \\ Tel: 44-127-765-2748Ｅ-mail: alan.thornton@anglia.ac.uk
}

Received: October 23, 2012

Accepted: November 14, 2012 Online Published: December 5, 2012

doi:10.5430/wje.v2n6p39

URL: http://dx.doi.org/10.5430/wje.v2n6p39

\begin{abstract}
With the continuing development of the Artist Teacher Scheme (ATS) it seems an opportune moment to ask the question: What is it to be an artist teacher in England today? The term 'artist teacher' and the concept it reflects are initially viewed here in a historical context. A conceptual model based on previous research into the education of artist teachers is proposed as a response to the ontological question. In this model artist teachers are understood as individuals committed to personal practice as art makers and art teachers who work predominantly but not exclusively in the secondary or tertiary sectors of art education. The article concludes by identifying some of the aims of the ATS and how they relate to art education, particularly in the maintained sector. Also it is proposed that the model presented could help artist teachers to focus beliefs and practices and that the education system should support the continuing professional development of these dual practitioners.
\end{abstract}

Keywords: Artist; teacher; education

\section{Introduction}

The Artist Teacher Scheme (ATS) was introduced in England in 1999 by the National Society for Education and Art (NSEAD) with support from the Arts Council of England (ACE) and the first two courses were pilot summer schools that took place in Liverpool and London. In 2004 there were seven centres and now there are ten (2012) in which higher education art departments usually in conjunction with galleries are running courses including part-time Master of Arts (MA) pathways for artist teachers. A definition of the artist teacher is provided in a pamphlet from one of the ATS summer schools: 'by artist teacher we mean practising artists who are also classroom practitioners' (Wimbledon School of Art, 2001). Also, over the years, the literature related to the scheme has provided further contextual definitions. However I believe the ontological question posed in the title needs further explication particularly as the ATS is being promoted as an important strategy of professional development for art teachers. In this article a conceptual model is formulated in order to give some clarity and understanding to the phenomenon of the artist teacher.

\section{The historical context}

Artist teachers appear to have a long pedigree with the artist apprentice tradition stretching back into pre-history. Daichendt in his book 'Artist Teacher' (2010) Claims that the English educationalist George Wallis (1811-1891) was the first artist teacher to be identified as such, and the term has been used intermittently in the literature since the $19^{\text {th }}$ century. However it begins to be seen more frequently as a representation of a type of practitioner in the late twentieth century. It is usually used as shorthand for 'the artist who is also a teacher of art' and it appears predominantly in publications from the USA. One of the most famous artist teachers referred to as such by Goldstein (1996), was Paul Klee who taught in the Weimar Bauhaus of 1919. Klee was highly productive as an artist throughout his years teaching at the Bauhaus. In the following quotation he refers to the course he was teaching as bound up with his art practice:

Here in the studio I work at half a dozen paintings and I am drawing and thinking about my course, everything together. For it has to go together, otherwise it wouldn't work at all (Klee.2002). 
Klee created an environment conducive to making his art and planning his teaching because he believed in the importance of both activities. He was already a renowned international artist at the time of taking up a teaching post at the Bauhaus, and it appears as if his decision to teach was largely based on his convictions regarding communicating art experience. Faass suggests that:

Klee himself seems at the time to have felt a kind of political obligation to teach. After the Munich "Raterepublic" (Socialist republic) had been suppressed, he declared himself convinced that modern artists in particular, by virtue of the originality of their thinking, could contribute to the future shaping of society. The precondition for this, he thought, was a new concept of education that would make their insights accessible to as many people as possible (Faass, 2000).

Klee of course worked in an art school at the tertiary level where it was, and still is, common for practising artists, designers etc, to teach specialist art students, a tradition prevalent in Europe, the USA and beyond. However historical changes since the $16^{\text {th }}$ Century, not least of all through the more comprehensive education of artists and the availability of education in art for a greater number of the population, has resulted in the notion of the artist teacher also becoming more relevant in the maintained sector in England, particularly at the secondary level. With the growth of general art education in the $19^{\text {th }}$ century, came the need for more teachers of art. Henry Cole, a major figure of art educational reform made provisions for training teachers of art in 1852. These fell into three categories: ..training existing schoolmasters and schoolmistresses, training pupil teachers and students in training colleges, and training masters for the Schools of Art (Macdonald, 1970:159).

Financial rewards were provided for teachers who passed appropriate examinations. It is here that we see the beginnings of a state approved professional class of art teachers in general education. In 1913 The Board of Education established the first national pedagogic course for art teachers called 'The Principles of Teaching and School Management'. The entry requirements were a school certificate and advanced training in art and passing this course gave students qualified teacher status. The one-year course involved methods of teaching and included teaching practice in schools. Leading schools of art were recognised as centres for the course. Macdonald says of this development: 'Full-time courses at Schools of Art, whether intentionally or not were now designed to produce teachers, not practising designers' (1970:304).

The 1944 Education Act in England consolidated education by formalising the rights of the majority of citizens to access it. The visual arts were commonly included in the curriculum of most primary and secondary schools. The increasing demand for art teachers, particularly at the secondary level, and the expectation that they would provide high standards of craft and teaching skills and artistic knowledge, resulted in an expansion of the professional class of art teachers. The present secondary Post Graduate Certificate in Education (PGCE in Art), in which a student has usually studied an art subject for at least three years to degree level before taking the one year course to qualify as a teacher, is a descendent of the first art teachers' course described above. The first Bachelor of Education (B.Ed) art degrees were developed in the 1960's. Macdonald speaks with enthusiasm of these:

This offered a unique opportunity for students to take art together with education and other academic subjects. While the art students at the colleges are encouraged to regard themselves as creative artists, the annual teaching practices, during which they take other subjects, confirm their roles as teachers. (1970:359).

The B.Ed degrees were replaced in the years to follow by the Bachelor of Arts (BA) degrees with Qualified Teacher Status (QTS). Although the time and resources made available for developing art knowledge and skills varied from institution to institution, both the PGCE and the BA with QTS courses offered qualifications for art teaching at the secondary and primary levels. We now have art specialists teaching at all levels of education and the phenomenon of the artist teacher extending beyond the tertiary sector. In these circumstances it seems appropriate to include all sectors in the formulation of a conceptual model of the artist teacher.

\section{A conceptual model of the artist teacher}

This model has been developed in order to offer some understanding of the artist teacher as a term, and as a phenomenon of practice. The following definition provides preliminary parameters for a contemporary model:

Artist teachers are individuals who produce artwork (art, craft or design work) and also teach art to students usually within the formal education system and, as the term implies, value both practices. However the time and energy they devote to each may vary according to personal desire or circumstances. For example full-time art teachers sometimes make art in their spare time; full-time artists sometimes teach in their spare time; and some artist teachers work part-time at both activities. Many artist teachers have art or art related qualifications and 
teaching qualifications, and are involved in teaching students at all levels of art education but predominately practice at the tertiary and secondary levels.

Models are used extensively in research and take many forms. The word 'model' can refer to diagrams, descriptions or a more encompassing construct. These include explanation building: "To "explain" a phenomenon is to stipulate a set of causal links about it' and Logic models: 'A logic model combines pattern matching and time series analysis' (Bickman, 1998). Descriptions are used predominantly here in order to present an encompassing definition of the contemporary artist teacher. This model is viewed as a helpful aid to understanding the phenomenon rather than a precise representation. Singleton and Straits make the point that:

'Since they are derived from tentative theories, models are never "correct" about social processes. Instead they serve as an economical and informed means of getting on with data analysis'(Singleton, 1999).

This model emerges from research based on historical impressions, identity theory and the reported practices and beliefs of individual artist teachers (Thornton, 2013: 15-90). It is not my intention to evoke an idealised artist teacher but a number of characteristics are identified and some tensions are highlighted. It is important to keep in mind that particular concepts relevant to the model are considered to overlap as well as interrelate. It is believed there is no contradiction in envisaging a concept as having defined parameters, or a holistic integrity whilst simultaneously being part of other concepts both influencing them and being influenced by them according to proximity of definitions and purposes (Wittgenstein, 2000:31e-32e). The concept of the artist teacher could be understood as being formed from two other concepts. We can envisage a concept of the teacher and a concept of the artist as separate circles but with parameters touching. We can also envisage a new circle, which overlaps the circle that represents the teacher and the one that represents the artist. This new circle represents the artist teacher. Each circle can stand for a defined concept overlapping other defined concepts. (Figure 1).

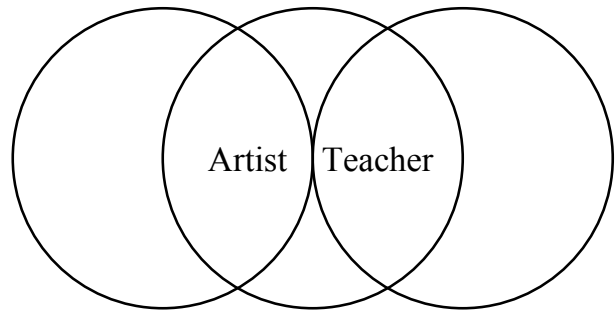

Figure 1: Overlapping concepts

On the one hand there are artists and teachers of art who are different practitioners. On the other there are individuals whose professional and personal identities and roles straddle these vocations in different ways and to varying degrees. Individuals have idiosyncratic conceptions of their roles and identities that sometimes, in some ways, coincide with those of others. It is such relationships that help to generate a conceptual model of the artist teacher. The following textual descriptions are presented as a list of characteristics, notions, practices, beliefs, observations and interpretations of who is, or what it means to be, an artist teacher in England today. They are summarised from more extensive research data (Thornton, 2003:27-114).

\section{Textual descriptions}

Artist teachers:

- have characteristics not dissimilar from those of artists who have taught their skills and knowledge to apprentices through master apprentice education and employment systems which are still present in the world and appear to have a lineage that stretches back into pre-history;

- have motivations and convictions based upon their art practice and exposure to the culture of art. They may also have maternal or paternal drives that make them amenable to supporting the nurturing of children or other needful individuals and a philosophical belief in the value of education;

- are influenced by notions of artistic autonomy derived from a historical trend often considered to have come to prominence in $16^{\text {th }}$ century Europe, developing in disparate ways to the present time. Although now society and the education system, to some extent, tolerate and even encourage artistic autonomy as an important factor in the production of quality art, some artist teachers are still aware of a tension that can exist between the 
socialising aspects of education and the autonomy of art and artists. The following quotation highlights this tension: "Groups can rob members of autonomy but can also provide identity and security" (Gillette, 1990:42);

- deep identification with art and teaching could be indicative of a function of identity regarding psychological stability and consistency or, philosophically, a reflection of the desire to be authentic in the world;

- reflect an interdependence of art and education. Some artists could be seen as highly dependent upon the patronage and support of education in contemporary societies. "..the teaching of a vast range of courses provides work for thousands of artists" Creedy, 1970:93). In England not only does the education system employ artist teachers but artists are also employed to work with teachers and students in residencies. Also public galleries with educational aims promote, sponsor and display artists work;

- self identification as such, could help to alleviate any sense of identity crisis by asserting the positive relationship between personal art making and teaching;

- $\quad$ are subject to the 'folklore' that colours perceptions of artistic personality and professionalism. In particular the perception that the artist necessarily must display an exclusive commitment to art making in order to be worthy of the identification. Also some perceptions of teaching can undermine the artist teacher identity. For instance the perception that teaching is no more than a 'safety net' for those who cannot find employment in other fields or professions;

- often have a strong historical and cultural identification or link with fine art practice. The choice of the word artist is reflective of this. However, in the spirit of conceptual overlap as representative of contemporary practice, this relationship is not considered exclusive. Artists in present day society often have diverse experiences and education and work with numerous media. Also postgraduate courses in education recruit students who have a variety of art-related experience and education, to train as teachers of art;

- $\quad$ practice at all levels of education. However this practice can vary according to the cultural context of the sector in question. The secondary sector would appear to exemplify the challenge of practising as an artist teacher. It is a major employer of fine art graduates in England but is also a demanding profession in which teachers have responsibilities regarding the education of children who are compelled to attend school and engage in the subjects taught. At tertiary level - particularly regarding fine art courses - teachers (tutors or lecturers) are often expected by their employers, to be art practitioners as well as teachers. This arguably gives professional substance to an identification of these practitioners as artist teachers. Also their students have usually developed motivation to make art through personal choices. These different contexts exert different pressures regarding maintaining dual practice. In addition to these two main provider groups are artist teachers in the primary, private and adult education sectors;

- $\quad$ are more able to sustain this dual practice or identity if they exhibit or present their art work, are regularly involved in producing art, are involved in the world of art beyond the education system and are supported by others artists or artist teachers;

- $\quad$ are more able to sustain this dual practice or identity if they are supported by teaching colleagues and senior management in the education institutions in which they work and the education system and society in general;

- $\quad$ need to develop strong self identifications in order to focus activities and beliefs;

- develop appropriate teaching strategies in order that their convictions, knowledge and art skills are effectively conveyed to others;

- value art as an important subject to teach as an aspect of students' general education as well as for a vocation;

- translate the world of art for students in order to help them understand its methods, philosophies, history and language, and also respect students' personal languages, cultures and interests and consider how these connect with the world of art;

- $\quad$ see their practice as a 'way of life' as well as a professional practice;

- see their practice as artists as an important aspect of their art teaching. Some may also see their teaching as an important aspect of their art practice;

- acknowledge differences between art made within educational institutions and art made outside them, but strive to interconnect these in various ways.

The following simplified definition of the artist teacher is presented as an indicator of the above model. 
An artist teacher is an individual who makes and teaches art and is dedicated to both activities as a practitioner.

This conceptual model is a representation of a human type. The model has stated parameters, which means that there are artist teachers whose practices, identities, roles or self-concepts locate within these parameters. Also the model is designed not just to reflect real practitioners, but to provide art teachers with an example of a professional practice they are able to relate to, or adapt their practices to reflect, in the interests of their personal and professional development.

\section{Conclusion}

The Artist Teacher Scheme (ATS) is one example of professional development for artist teachers. The scheme usually involves collaborations between art education institutions and galleries and the emphasis is on developing students' artistry rather than their pedagogy. However it is claimed in literature relating to the scheme that developing the artistry of teachers not only offers them personal artistic continuity, but also the possibility of extending and informing their teaching. According to one of the summer school pamphlets the overall aims of the ATS are to:

enable teachers to reflect on and develop their practice as artists.

raise standards in art and design education by relating pedagogy to the highest levels of contemporary art practice.

extend lifelong learning in art and design by developing strong links between artist teachers, schools, galleries, museums, higher education institutions and artists.

provide opportunities for artist teachers to receive appropriate accreditation at postgraduate level (Tate Modern, 2001).

The term 'artist teacher' is already appearing more frequently in the literature in England particularly in relationship to the ATS. This could encourage art teachers to think about the concept and how it might relate to their sense of personal and professional identity. Unfortunately just as this scheme begins to gain momentum and credibility within the maintained sector, art and design is suffering the effects of second class status in the national curriculum accompanied by withering resources particularly in schools and teacher education departments (Rodgers, 1998). Also art teachers in common with all teachers are experiencing ever increasing demands on their time and energy thus, also creating pressure on them to find the time and energy to practice as artist teachers. However it is encouraging to see NSEAD and ACE promoting this identity and art teachers and artist teachers from all sectors attending and valuing the courses on offer.

The conceptual model presented in this article provides some parameters for identifying the phenomenon in the belief that this could help individuals with such an orientation, to focus ideas and practices. In a sense the communication of art knowledge and skills are largely dependent on the personal and professional identities of art teachers. People who construct themselves as artist teachers do so because both activities are considered necessary regarding their sense of being. The education system - representing the interests of students and teachers in every sector, at every age, in the spirit of life long learning - could do well to invest in the artistic development as well as the pedagogic development of art teachers whose knowledge and skills are the life blood of their teaching.

\section{References}

Bickman, L., \& Rog, D. J. (1998) Handbook of Applied Social Research Methods. London, Sage.

Creedy, J. (1970). The Social Context of Art. London, Tavistock.

Daichendt, J. (2010). Artist Teacher. USA, Intellect.

Faass, M. (2000). Paul Klee, in: Fiedler, J. \& Feierabend, P. [eds], Bauhaus, Cologne, Konemann.

Gillette, J., \& McCollom, M. (1990). Groups in Context. USA, Addison-Wesley Goldstein, C. (1996) Teaching Art, Cambridge, University Press.

Klee, P. (2002). The Nature of Creation [exhibition information]. London, Hayward Gallery.

Macdonald, S. (1970). History and Philosophy of Art Education. London, University of London Press. 
Rogers, R. (1998). The Disappearing Arts? London, Royal Society of Arts.

Singleton, R. A., \& Straits, B. C. (1999) Approaches to Social Research. Oxford, University Press.

Thornton, A. (2003). Educating the Artist Teacher, EdD Thesis, Anglia Polytechnic University.

Thornton, A. (2013). Artist, Researcher, Teacher. Bristol, Intellect, UK and Chicago, Chicago Press, USA.

Wimbledon School of Art. (2001). Pamphlet. London, WSA.

Wittgenstein, L. (2000). Philosophical Investigations. Oxford, Blackwell. 